\title{
ANTIMICROBIAL ACTIVITY OF ENTEROCOCCUS FAECIUM FAIR-E 198 AGAINST GRAM-POSITIVE PATHOGENS
}

\author{
Maristela da Silva do Nascimento ${ }^{1,2 *}$, Izildinha Moreno ${ }^{1}$, Arnaldo Yoshiteru Kuaye ${ }^{2}$ \\ ${ }^{1}$ Instituto de Tecnologia de Alimentos, Campinas, SP, Brasil; ${ }^{2}$ Departamento de Tecnologia de Alimentos, Faculdade de \\ Engenharia de Alimentos, Universidade Estadual de Campinas, Campinas, SP, Brasil
}

Submitted: August 28, 2008; Returned to authors for corrections: March 30, 2009; Approved: September $28,2009$.

\begin{abstract}
This study investigated the antimicrobial activity of Enterococcus faecium FAIR-E 198 against Bacillus cereus, Listeria monocytogenes and Staphylococcus aureus. Using the critical-dilution method, the bacteriocin produced by E. faecium FAIR-E 198 inhibited all L. monocytogenes strains evaluated (1,600 to 19,200 AU mL ${ }^{-1}$ ). However, none of the B. cereus and $S$. aureus strains investigated were inhibited. The maximum activity of this bacteriocin (800 $\mathrm{AU} \mathrm{mL} \mathrm{mL}^{-1}$ ) was observed in MRS broth, while the activity in milk was $100 \mathrm{AU} \mathrm{mL}{ }^{-1}$. In the co-cultivation test in milk, B. cereus K1-B041 was reduced to below the detection limit (1.00 log CFU mL $\mathrm{mL}^{-1}$ ) after $48 \mathrm{~h}$. E. faecium reduced the initial L. monocytogenes Scott A population by $1 \log \mathrm{CFU} \mathrm{mL}{ }^{-1}$ after $3 \mathrm{~h}$ at $35^{\circ} \mathrm{C}$. However, the pathogen regained growth, reaching $3.68 \log$ $\mathrm{CFU} \mathrm{mL} \mathrm{m}^{-1}$ after $48 \mathrm{~h}$. E. faecium did not influence the growth of $S$. aureus ATCC 27154 during the $48 \mathrm{~h}$ of co-cultivation. Therefore, it can be concluded that the effectiveness of the antimicrobial activity of $E$. faecium FAIR-E 198 is strictly related to the species and strain of the target microorganism and to the culture medium.
\end{abstract}

Key words: Enterococcus faecium, bacteriocin, biopreservation, gram-positive pathogen

\section{INTRODUCTION}

The potential risk posed by the presence of pathogens in dairy products is a constant concern in the field of food safety for both the food processing industry and government authorities. A number of foodborne disease outbreaks have been associated with these products (19). Although most of these outbreaks were closely related with the consumption of dairy products made from raw milk $(5,7)$, post-processing contamination must be taken into account as an important risk factor in the manufacture of such products.
Reduction of $\mathrm{pH}$ due to the production of organic acids, particularly lactic acid, by fermentation of naturally occurring carbohydrates in foods is responsible for the main antagonistic effect against a series of different microorganisms. However, nutrient competition and the formation of other compounds with inhibitory activity (hydrogen peroxide, diacetyl and bacteriocin) are important antimicrobial functions of lactic-acid bacteria (17). Bacteriocins are peptides or proteins with antimicrobial activity that are synthesized by the ribosomes of lactic-acid bacteria.

Numerous reports describing bacteriocin activity in 
Enterococcus species have been published in recent years. Most of the bacteriocin producer strains have been isolated from dairy products $(10,23)$. Some of these species, particularly Enterococcus faecium, provide probiotic and technological benefits, including the ability to grow at refrigeration temperatures over a wide $\mathrm{pH}$ range and in the presence of up to $6.5 \% \mathrm{NaCl}(4,20)$, in addition to improving cheese flavor. However, there is controversy in literature regarding its pathogenic potential. Giraffa et al. (14) state that, like other lactic-acid bacteria, enterococci species may occasionally be involved in clinical infections, but that in spite of this, many strains are considered safe for use in foods. An example of such a strain is E. faecium K770, which was approved in 1996 in the United Kingdom for use in cultured dairy products (13).

E. faecium FAIR-E 198, a strain isolated from Greek Feta cheese, is a bacteriocin producer (26) and was found to be a poor acidifier in milk (25). In general, enterocins have selective antimicrobial activity against the genus Listeria and are not effective against lactic acid bacteria $(16,20)$. However, some authors observed activity of enterocins against other Grampositive pathogens like Bacillus cereus (9) and Staphylococcus aureus (2). This suggests that bacteriocinogenic entrococci strains or their enterocins may be used to enhance the microbiological safety of fermented dairy products.

The aim of this study was to verify the viability of using $E$. faecium FAIR-E 198 as an adjunct culture in dairy products to control gram-positive pathogens. To this end, the growth and production of the bacteriocin by E. faecium FAIR-E 198 in MRS broth and milk was evaluated and the spectrum of antimicrobial activity was determined. In addition, the behavior of Bacillus cereus, Listeria monocytogenes and Staphylococcus aureus during co-cultivation with this bacteriocins-producing bacterium in milk were analyzed.

\section{MATERIALS AND METHODS}

\section{Bacterial strains and media}

Bacterioci- producing Enterococcus faecium FAIR-E 198

(strain ACA-DC 1618, Laboratory of Dairy Research,
Agricultural University of Athens, Greece) was isolated from Feta cheese (26). This strain was stored at $4{ }^{\circ} \mathrm{C}$ in de Man Rogosa Sharpe (MRS) broth (Difco, Becton Dickinson, Sparks, MD). The pathogenic bacteria were purchased from the Faculty of Food Engineering, Campinas State University (Campinas, Brazil) and the Bacterial Collection of the Oswaldo Cruz Foundation (Rio de Janeiro, Brazil). Listeria monocytogenes strains were maintained in trypticase soy agar supplemented with $0.6 \%$ yeast extract (TSA-YE, Difco), Staphylococcus aureus in brain-heart infusion agar (BHI, Difco) and Bacillus cereus in trypticase soy agar (TSA, Difco). Before being used in the tests, the strains were grown in media and at temperature indicated for each culture.

\section{Pathogenicity tests}

Gelatinase production was determined in nutrient gelatin agar (Difco) after incubation at $37^{\circ} \mathrm{C}$ for up to seven days. A positive reaction was indicated by liquefaction of the medium after incubation at $21{ }^{\circ} \mathrm{C}$ for two hours. Thermonuclease activity was assessed using Bacto-DNAse Test agar (Difco) supplemented with $0.83 \%$ toluidine blue (Sigma-Aldrich, Saint Louis, MO.). Each well made in the agar was filled with aliquots of $50 \mu \mathrm{L}$ of the strain that had been previously heated for $15 \mathrm{~min}$ at $100{ }^{\circ} \mathrm{C}$. The presence of a pink coloration around the wells after incubation for $24 \mathrm{~h}$ at $37^{\circ} \mathrm{C}$ was indicative of thermonuclease activity (3).

\section{Determination of antimicrobial spectrum}

The sensitivity of $25 \mathrm{~B}$. cereus strains, ten $L$. monocytogenes strains and five $S$. aureus strains to the bacteriocin produced by E. faecium FAIR-E 198 were evaluated using an adapted critical-dilution method (18). Culture plates were prepared with TSB soft agar (0.9\% agar) and TSB-YE soft agar previously inoculated with $1 \%(0.2 \mathrm{~mL})$ of the B. cereus, S. aureus and L. monocytogenes $\left(10^{6}-10^{7} \mathrm{CFU}\right.$ $\mathrm{mL}^{-1}$ ) cultures, respectively. The overnight bacteriocinogenic cultures were centrifuged at $7,500 \times \mathrm{g}$ for $15 \mathrm{~min}$ at $4^{\circ} \mathrm{C}$ (Beckman J2-21 Centrifuge, Palo Alto, Calif.). The supernatants were adjusted to $\mathrm{pH} 6.5$ and sterilized by filtration 
through a $0.22 \mu \mathrm{m}$ membrane (Millipore, Carrigtwohill, Ireland). Then, $10 \mu \mathrm{L}$ of serial two-fold dilutions of cell-free culture supernatants in $10 \mathrm{mM}$ sodium phosphate buffer, $\mathrm{pH}$ 7.0, were spotted onto plates containing the pathogens. The plates were incubated for $24 \mathrm{~h}$ at $35{ }^{\circ} \mathrm{C}$. The bacteriocin activity was expressed in arbitrary units per milliliter $\left(\mathrm{AU} \mathrm{mL}^{-}\right.$

${ }^{1}$ ), corresponding to the reciprocal of the highest dilution causing a clear inhibition zone on the indicator strain and was multiplied by a factor of 100 .

\section{Effect of culture media on bacteriocin production}

The cell suspensions, containing approximately $10^{5}-10^{6}$ $\mathrm{CFU} \mathrm{mL} \mathrm{m}^{-1}$ of the bacteriocinogenic culture, were inoculated into MRS broth and into $10 \%$ reconstituted skim milk powder (RSM). The inoculated samples were incubated at $37^{\circ} \mathrm{C}$ for 48 $\mathrm{h}$. Then, samples of the cultures were collected at $3 \mathrm{~h}$ intervals during the first $12 \mathrm{~h}$ and after 24 and $48 \mathrm{~h}$ of incubation. Microbial counts were determined by plating onto $\mathrm{KF}$ Streptococcus agar (Difco) and incubated at $37^{\circ} \mathrm{C}$ for $48 \mathrm{~h}$. The $\mathrm{pH}$ was determined by a $\mathrm{pH}$-meter (Hanna Instruments HI 9110, Singapore). Bacteriocin production was determined by the critical-dilution method using L. monocytogenes Scott A as an indicator microorganism.

\section{Co-cultivation of gram-positive pathogens and FAIR-E 198 in milk}

The bacteriocin-producing culture $\left(10^{6}-10^{7} \mathrm{CFU} \mathrm{mL} \mathrm{m}^{-1}\right)$ was cultivated separately with $B$. cereus K1-B041, $L$. monocytogenes Scott A and S. aureus ATCC 27154 (approximately $10^{2} \mathrm{CFU} \mathrm{mL} \mathrm{m}^{-1}$ ) in RSM and incubated at $35^{\circ} \mathrm{C}$ for $48 \mathrm{~h}(6,24)$. Milk samples individually inoculated with each of the species investigated were used as control. Samples were collected after $0,3,6,9,12,24$ and 48 h of incubation. $E$. faecium counts were performed on KF Streptococcus plates after incubation at $37{ }^{\circ} \mathrm{C}$ for $48 \mathrm{~h}$. Modified Oxford agar (Difco) was used for L. monocytogenes, Baird-Parker agar (Difco) for S. aureus, both of which were incubated at $35^{\circ} \mathrm{C}$ for $48 \mathrm{~h}$, and Mannitol-Egg-yolk-Polymyxin agar (MYP, Difco) was used for B. cereus, with incubation at $30{ }^{\circ} \mathrm{C}$ for 24 h. The identity of the colonies recovered in the selective media was confirmed using biochemical tests (12). Immediately upon collection, the $\mathrm{pH}$ of each sample was measured by a $\mathrm{pH}$ meter. The bacteriocin activity against the three pathogens investigated was determined by the critical-dilution method.

\section{Statistical analysis}

Analysis of variance (ANOVA) and the Tukey test at the $5 \%$ level of significance were used to compare means among and within experimental groups.

\section{RESULTS AND DISCUSSION}

\section{Pathogenicity potential}

Before being used in food technology, all enterococci strains must have their pathogenicity factors carefully analyzed. The results of the pathogenicity tests performed showed that E. faecium FAIR-E 198 was negative for gelatinase and thermonuclease activities. In previous studies, this strain was non-hemolytic when tested on sheep or human blood, and exhibited no resistance to vancomycin and teicoplanin $(26,28)$. All the above characteristics are indicative of the absence of pathogenicity. However, more tests are necessary to confirm this, such as the identification of virulence genes.

\section{Spectrum of activity}

The use of bacteriocins or bacteriocinogenic cultures in biopreservation of foods may be considered as an additional tool to enhance the microbiological safety and reduce the risk of the development of spoilage microorganisms. In this study, the enterocin produced by E. faecium FAIR-E 198, like most Class IIa bacteriocins, showed activity predominantly against L. monocytogenes, inhibiting all ten strains evaluated (1,600 to 19,200 $\mathrm{AU} \mathrm{mL} \mathrm{m}^{-1}$ ) by the critical-dilution method. The differing susceptibility observed in L. monocytogenes strains and the absence of sensitivity shown by all the $25 \mathrm{~B}$. cereus and five $S$. aureus strains to the bacteriocin (Table 1) can be explained by natural variation in susceptibility and the ability to develop 
resistance to bacteriocins. Ennahar and Deschamps (11) observed that enterocin A produced by E. faecium EFM01 inhibited 13 out of a total of 14 L. monocytogenes strains, while none of $7 \mathrm{~S}$. aureus strains investigated were inhibited by this bacteriocin. On the other hand, Ammor et al. (2) reported antimicrobial activity of enterocins produced by E. faecium against $S$. aureus strains.

Table 1. Antimicrobial spectrum of the bacteriocin produced by E. faecium FAIR-E 198.

\begin{tabular}{llc}
\hline Pathogen specie & Strain & $\begin{array}{c}\text { Inhibitory activity } \\
(\mathbf{A U} / \mathbf{m L})\end{array}$ \\
\hline Listeria monocytogenes & IOC $^{a} 1551$, SCOTT A & 1.600 \\
& IOC 1324, ATCC 19111, ATCC 7644 & 3.200 \\
& IOC 1630 & 4.800 \\
& IOC 1359, IOC 1898 & 6.400 \\
& ATCC 19115 & 12.800 \\
IOC 1527 & 19.200
\end{tabular}

Staphylococcus aureus

ATCC 8095, ATCC 13565, ATCC 19095, ATCC

27154, ATCC 27664

$\mathrm{ND}^{d}$

Bacillus cereus

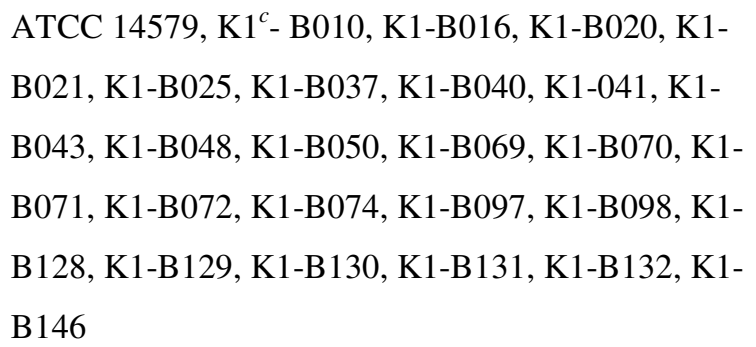

\footnotetext{
${ }^{a}$ IOC: Instituto Oswaldo Cruz (Rio de Janeiro, BR)

${ }^{b}$ ATCC: American Type Culture Collection (Rockville, USA),

${ }^{c}$ K1: Faculdade de Engenharia de Alimentos, Universidade Estadual de Campinas (Campinas, BR),

${ }^{d}$ Not detected.
}

\section{Bacteriocin production in MRS broth and milk}

The production of bacteriocins by E. faecium FAIR-E 198 was influenced by the culture medium. In MRS broth, this strain reached a maximum population level of $7.90 \log \mathrm{CFU}$ $\mathrm{mL}^{-1}$ after $12 \mathrm{~h}$, remained stable up to $24 \mathrm{~h}$ of incubation, but decreased by $1 \log$ CFU mL $\mathrm{m}^{-1}$ after $48 \mathrm{~h}$. Acidification of the MRS broth began after $6 \mathrm{~h}$, resulting in a pH of 3.72 after $48 \mathrm{~h}$. The bacteriocin activity, measured using L. monocytogenes Scott $\mathrm{A}$ as an indicator microorganism, was first detected after $9 \mathrm{~h}$ of incubation (100 $\mathrm{AU} \mathrm{mL} \mathrm{m}^{-1}$ ), during the log-phase, and reached a maximum of $800 \mathrm{AU} \mathrm{mL}^{-1}$ after $24 \mathrm{~h}$, during the stationary phase (Fig. 1A). However, several authors have reported maximum enterocin activity during or at the end of the exponential growth phase $(1,26)$. The pronounced decrease in bacteriocin activity $(87.5 \%)$ observed after $24 \mathrm{~h}$ may be related to protein aggregation, proteolytic inactivation or adsorption of the bacteriocin onto the producer cell surface (8).

In milk, E. faecium FAIR-E 198 reached a count of 8.10 $\log$ CFU mL $\mathrm{mL}^{-1}$ after $24 \mathrm{~h}$, followed by a drop of $0.90 \log \mathrm{CFU}$ $\mathrm{mL}^{-1}$ after $48 \mathrm{~h}$. During bacterial growth, the $\mathrm{pH}$ of the milk 
decreased from 6.45 to 5.08. Bacteriocin activity was observed only after $6 \mathrm{~h}\left(100 \mathrm{AU} \mathrm{mL} \mathrm{m}^{-1}\right)$ and was no longer detected up until the end of the incubation period (Fig. 1B). Sarantinopoulos et al. (26) evaluated this same strain and obtained a similar result using milk supplemented with casein hydrolysate (1.4\%). According to Moreno et al. (20), the enterococci showed low proteolytic activity and consequently slower metabolism. This fact might be the reason why bacteriocin production in milk is lower than in broth. Another explanation for the low enterocin activity in milk may lie in interactions of this substance with milk components, such as fat and casein (21).

\section{$\mathbf{A}$}

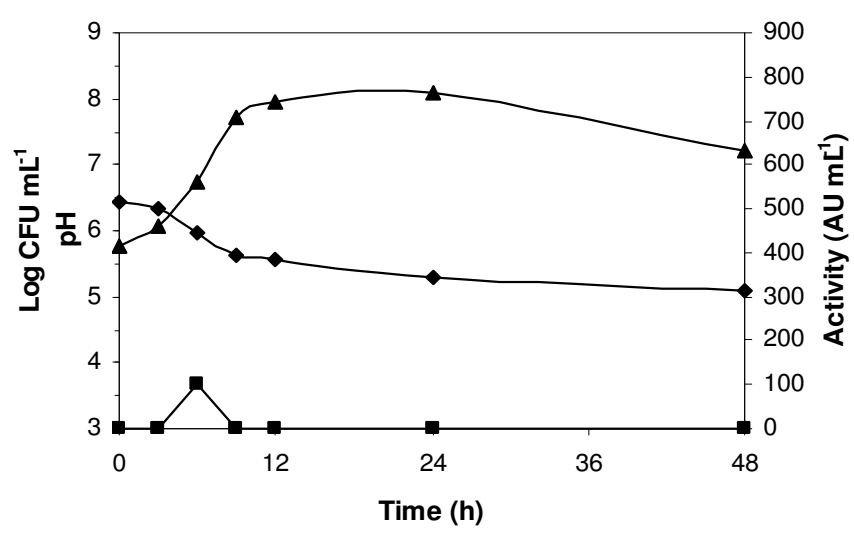

$\mathbf{B}$

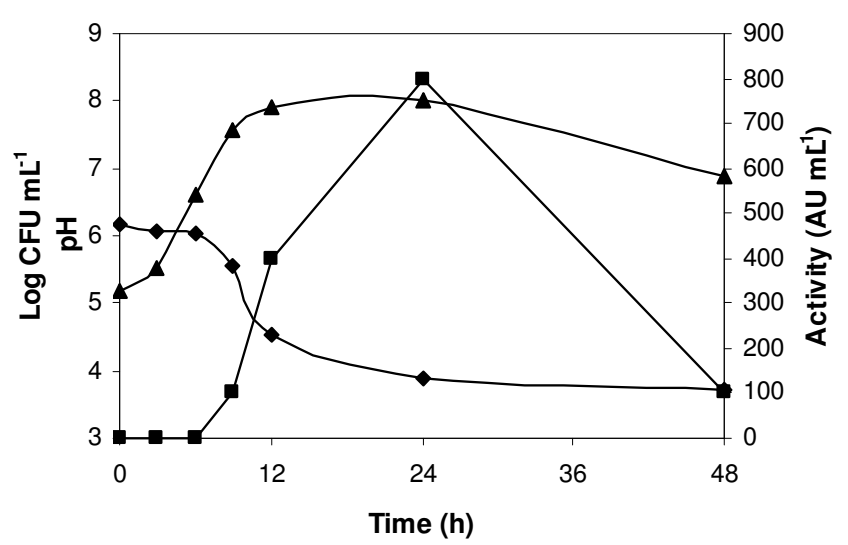

Figure 1. Growth of Enterococcus faecium FAIR-E 198 in MRS broth (A) and skim milk (B). Growth $(\mathbf{\Delta})$, bacteriocin activity against $L$. monocytogenes Scott A (๘) and $\mathrm{pH}(\diamond)$.

\section{Co-cultivation with Gram-positive pathogens}

The initial counts $\left(2 \log \mathrm{CFU} \mathrm{mL} \mathrm{m}^{-1}\right)$ of the pathogens used in these tests were based on the contamination level normally found in dairy products. B. cereus K1-B041 in the control sample reached a count of $8.37 \log \mathrm{CFU} \mathrm{mL} \mathrm{m}^{-1}$ after a 48 -h incubation (Fig. 2A). During the first $24 \mathrm{~h}$ of co-cultivation with the bacteriocinogenic culture, no significant reduction $\left(<0.70 \log \mathrm{CFU} \mathrm{mL}^{-1}\right)$ was observed in the B. cereus population. However, after $48 \mathrm{~h}$, this pathogen population was reduced to below the detection limit $\left(<1.00 \log \mathrm{CFU} \mathrm{mL}^{-1}\right)$. The bacteriocinogenic culture reached viable cell counts of $8.13 \log \mathrm{CFU} \mathrm{mL} \mathrm{m}^{-1}$ after $48 \mathrm{~h}$. No bacteriocin activity against $B$. cereus was detected during $48 \mathrm{~h}$ of incubation. A significant difference $(\mathrm{P} \leq 0.05)$ was observed between the $\mathrm{pH}$ values of the control sample and the co-cultivation sample after $9 \mathrm{~h}$. Therefore, the significant reduction of the B. cereus K1-B04 population observed after $48 \mathrm{~h}$ of co-culture with E. faecium FAIR-E 198 may be attributed to the reduction of the $\mathrm{pH}$ to lower than 4.4. Wong and Chen (29) reported that the development of $B$. cereus is impaired when the $\mathrm{pH}$ of the culture medium is lower than 5. According to Rossland et al. (24), a rapid decrease of the $\mathrm{pH}$ at the beginning of the logarithmic phase would be strongly related to pathogen inhibition.

The effect of the bacteriocin produced by E. faecium FAIR-E 198 on the cell viability of L. monocytogenes Scott A during growth in milk is shown in Figure 2B. The control sample, initially inoculated with $2.63 \log \mathrm{CFU} \mathrm{mL} \mathrm{m}^{-1}$ of $L$. monocytogenes, reached a population of $7.26 \log \mathrm{CFU} \mathrm{mL}$ after $48 \mathrm{~h}$. The bactericidal activity of E. faecium reduced the L. monocytogenes Scott A count from 2.19 to $1.15 \log \mathrm{CFU}$ $\mathrm{mL}^{-1}$ during the first $3 \mathrm{~h}$ of incubation, after which the remaining bacterial cells regained growth, attaining $3.68 \mathrm{log}$ CFU mL $\mathrm{m}^{-1}$ after $48 \mathrm{~h}$ of incubation. During the same period, the population of the bacteriocinogenic culture increased from 6.00 to $7.32 \log \mathrm{CFU} \mathrm{mL} \mathrm{mL}^{-1}$. Bacteriocin activity $\left(100 \mathrm{AU} \mathrm{mL} \mathrm{mL}^{-1}\right)$ produced by this culture was detected only in the sample analyzed after a 6-h incubation. The $\mathrm{pH}$ values of the cocultivated E. faecium sample were lower than the $\mathrm{pH}$ values of 
the control sample containing only L. monocytogenes over the entire incubation period. After $48 \mathrm{~h}$, the $\mathrm{pH}$ of the co-cultivated sample was 5.30, while the control sample exhibited a $\mathrm{pH}$ value of 6.10. The reductions of $L$. monocytogenes obtained in this study were greater than those reported by Elotmani et al. (9), using another E. faecium strain. The initial bactericidal effect of E. faecium FAIR-E 198 against L. monocytogenes Scott A and the subsequent growth recovery of the pathogen may be related to the production of amounts of bacteriocin insufficient to inhibit all the cells of the target microorganism. A similar phenomenon has previously been commented upon by Muriana (22) with respect to other bacteriocinogenic cultures.

In relation to $S$. aureus ATCC 27154, the control sample initially inoculated with $2.79 \log \mathrm{CFU} \mathrm{mL} \mathrm{mL}^{-1}$ exhibited a population of $8.80 \log \mathrm{CFU} \mathrm{mL} \mathrm{mL}^{-1}$ after $24 \mathrm{~h}$ (Fig. 2C). This was followed by a decline phase, and after $48 \mathrm{~h}$ of incubation, the $S$.

A

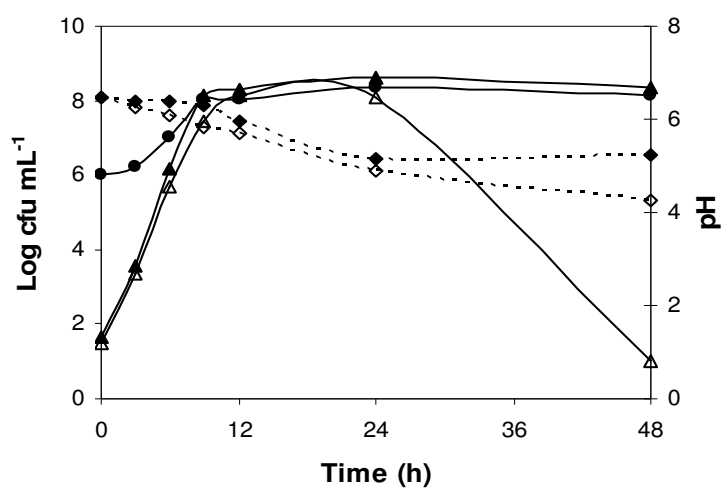

$\mathbf{B}$

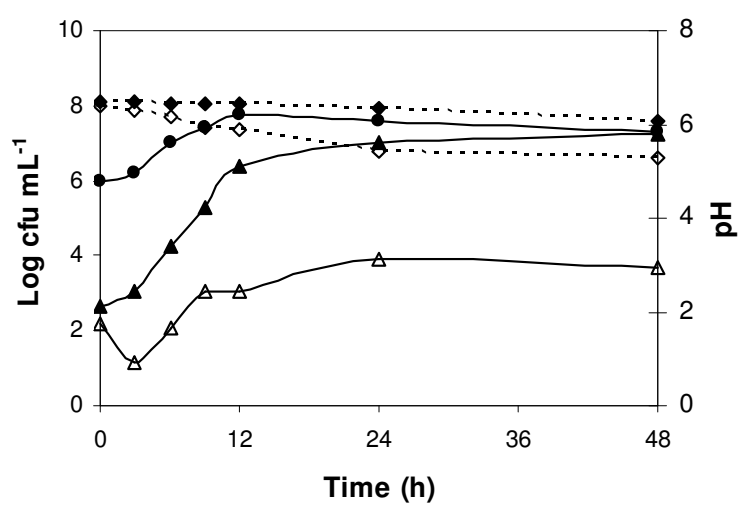

aureus reached a viable cell count of $7.10 \log \mathrm{CFU} \mathrm{mL} \mathrm{m}^{-1}$. The count of the bacteriocinogenic culture increased by $2.00 \log$ CFU mL $\mathrm{mL}^{-1}$ after $48 \mathrm{~h}$. Nonetheless, no bacteriocin activity of any kind against $S$. aureus was observed throughout the incubation period. No significant difference $(\mathrm{P} \geq 0.05)$ was found between the $\mathrm{pH}$ of the $S$. aureus control sample and the co-cultivation sample. E. faecium FAIR-E 198 did not show bacteriocin activity or any other significant inhibitory effect $(\mathrm{P} \geq 0.05)$ against $S$. aureus ATCC 27154 during the $48 \mathrm{~h}$ incubation. According to Sutra et al. (27) Staphylococcus possess the ability to form a viscous or gelatinous polysaccharide capsule that prevents the penetration of antimicrobial substances into the bacterial cells. However, Lauková et al. (15) studied the effect of enterocin CCM 4231 on the growth of $S$. aureus in milk and observed a reduction in the number of viable cells of the pathogen from $10^{10} \mathrm{CFU} \mathrm{mL} \mathrm{m}^{-1}$ to $10^{2} \mathrm{CFU} \mathrm{mL} \mathrm{m}^{-1}$ after a $24-\mathrm{h}$ incubation.

C

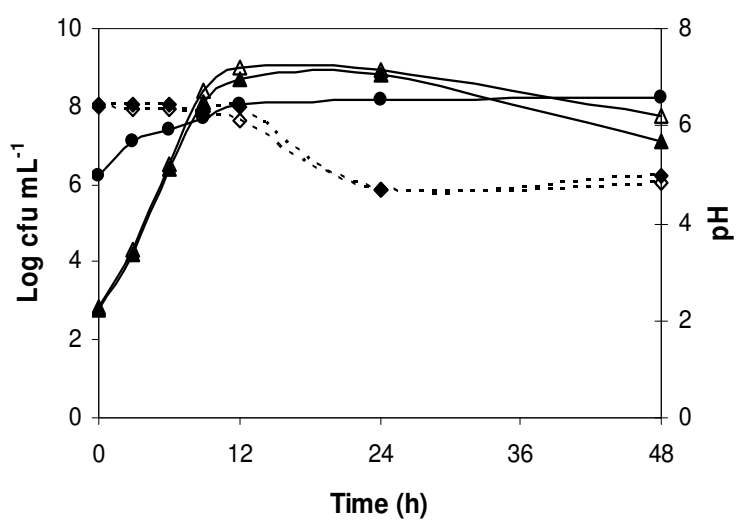

Figure 2. Growth evolution of co-culture of (A) B. cereus $\mathrm{K} 1-\mathrm{B} 041$, (B) L. monocytogenes Scott A or (C) S. aureus ATCC 27154 with E. faecium FAIR-E 198 in skim milk during $48 \mathrm{~h}$ at $35^{\circ} \mathrm{C}$. E. faecium FAIR-E 198 counts $(\bullet-\bullet)$ in co-cultivation. Pathogen counts in culture control $(\boldsymbol{\Delta}-\boldsymbol{\Delta})$ or in co-cultivation with E. faecium FAIR-E $198(\Delta-\Delta)$. pH of the media in co-cultivation $(\diamond----\diamond)$ and in culture control of pathogen $(\bullet---\downarrow)$. 


\section{CONCLUSION}

The effectiveness of the antimicrobial activity of $E$. faecium FAIR-E 198 is strictly related to the species and strain of the target microorganism and to the culture medium. This lactic-acid bacterium shows interesting characteristics for use as an additional safety provision within the context of hurdle technologies to interact with other barriers for the control of foodborne Gram-positive pathogens in dairy products. However, to this end, more studies on virulence factors and antibiotic resistance are necessary.

\section{ACKNOWLEDGEMENTS}

The authors wish to thank Dr. Effie Tsakalidou (Agricultural University of Athens, Greece) for providing $E$. faecium FAIR-E 198. This research project was funded by the Fundação de Amparo a Pesquisa do Estado de São Paulo (FAPESP) and Conselho Nacional de Desenvolvimento Científico e Tecnológico (CNPq).

\section{REFERENCES}

1. Alvarado, C.; Garcia-Almendárez, B.E.; Martin, S.E.; Regalado C. (2005). Anti-Listeria monocytotgenes bacteriocin-like inhibitory substances from Enterococcus faecium UQ31 isolated from artisan mexican-style cheese. Cur. Microbiol., 51:110-115.

2. Ammor, S.; Tauveron, G.; Dufour, E.; Chevallier, I. (2006). Antibacterial activity of lactic acid bacteria against spoilage and pathogenic bacteria isolated from the same meat small-scale facility. 1-Screening and characterization of the antibacterial compounds. Food Cont., 17:454-461.

3. Brolazo, E.M. (2003). Seleção e utilização de bactérias lácticas produtoras de diacetil em leite e derivados. Campinas, Brasil. 98p. (M. Sc. Dissertation. Instituto de Biologia. Unicamp).

4. Cintas, L.M.; Casaus, P.; Havarstein, L.S.; Hernandez, P.E.; Nes, I.F. (1997). Biochemical and genetic characterization of enterocin $\mathrm{P}$, a novel sec-dependent bacteriocin from Enterococcus faecium P13 with a broad antimicrobial spectrum. Appl. Environ. Microbiol., 63:4321-4330.

5. Center for Disease Control (CDC). (2001). Outbreak of listeriosis associated with homemade mexican-style cheese - North Carolina, October 2000 - January 2001. Available at: http://www.cdc.gov/mmwr/preview/mmwrhtml/mm 5026a3.htm.
6. Davies E. A.; Bevis, H. E.; Delves-Broughton, J. (1997). The use of the bacteriocin, nisin, as a preservative in ricotta-type cheeses to control the food-borne pathogen Listeria monocytogenes. Lett. Appl. Microbiol., 24: 343-346.

7. De Buyser, M.L.; Dufour, B.; Marie, M.; Lafarge, V. (2001). Implication of milk and milk products in foodborne diseases in France and in different industrialized countries. Int. J. Food Microbiol., 67:1-17.

8. De Vuyst, L.; Vandamme, E.J. (1994). Bacteriocins of lactic acid bacteria. Blackie Academic and Professional, London, 539p.

9. Elotmani, F.; Revol-Junelles, A.M.; Assobhei, O.; Milliére, J. (2002). Characterization of anti-Listeria monocytogenes bacteriocins from Enterococcus faecalis, Enterococcus faecium and Lactococcus lactis strains isolated from Raib, a Moroccan tradicional fermented milk. Cur. Microbiol., 44:10-17.

10. Ennahar, S.; Aoude-Werner, D.; Assobhei, O.; Hasselmann, C. (1998). Antilisterial activity of enterocin 81, a bacteriocin produced by Enterococcus faecium WHE 81 isolated from cheese. J. Appl Microbiol., 85:521-526.

11. Ennahar, S.; Deschamps, N. (2000). Anti-Listeria effect of enterocin A, produced by cheese-isolated Enteroccoccus faecium EFM01, relative to other bacteriocins from lactic acid bacteria. J. Appl. Microbiol., 88:449457.

12. Food and Drug Administration. (1998). Bacteriological Analytical Manual Online. $8^{\text {th }}$ ed., Revision A. http://www.cfsan.fda.gov/ebam.html.

13. Giraffa, G. (2003). Functionality of enterococci in dary products. Int. J. Food Microbiol., 88:215-222.

14. Giraffa, G.; Carminati, D.; Neviani, E. (1997). Enterococci isolated from dairy products: review of risks and potential technological use. J. Food Prot, 60:732-738.

15. Lauková, A.; Czikková, S.; Dobransky, T.; Burdova, O. (1999). Inhibition of Listeria monocytogenes and Staphylococcus aureus by enterocin CCM 4231 in milk products. Food Microbiol., 16:93-99.

16. Lauková, A.; Vlaemynck, G.; Czikkova, S. (2001). Effect of enterocin CCM 4231 on Listeria monocytogenes in Saint-Paulin cheese. Folia Microbiol., 46:157-160.

17. Magro, M.L.M.;Corbacho, J.M.M.; Sorribes, C.H.; Gea, A.M.S.; Gomez, J.M.G. (2000). Las bacteriocinas de las bacterias lácticas 1: Definición, classificación, caracterización y métodos de detección. Alimentaria, 37:59-66

18. Mayr-Harting, A.; Hedges, A.J.; Berkeley, C.W. (1972). Methods for studying bacteriocins. In: Norris, J.R.; Ribbons, D.W. (Eds.), Methods in Microbiology, vol. 7. Academic Press Inc., New York, p.315-422.

19. Mead, P.S.; Slutsker, L.; Dietz, V.; Mccaig, L.F.; Bresee, J.S.; Shapiro, C.; Griffin, P.M.; Tauxe, R.V. (1999). Food-related illness and death in the United States. Emerg. Infect. Dis., 5:607-625.

20. Moreno, M.R.F.; Rea, M.C.; Cogam, T.M.; De Vuyst, L. (2002). Applicability of a bacteriocin-producing Enterococcus faecium as a coculture in Cheddar cheese manufacture. Int. J. Food Microbiol. 81:73-84. 
21. Muñoz, A.; Maqueda, M.; Gálvez, A.; Martinéz-Bueno, M.; Rodriguez, A.; Valdivia, E. (2004). Biocontrol of psychrotrophic enteroxigenic Bacillus cereus in a non fat hard cheeseby na enterococcal strainproducing enterocin AS-48. J. Food Prot., 67:1517-1521.

22. Muriana, P.M. (1996). Bacteriocins for control of Listeria spp. in food. J. Food Prot., Supplement 56:54-63.

23. Nunez, M.; Rodriguez, J.L.; Garcia, E.; Gaya, P.; Medina, M. (1997). Inhibition of L. Monocytogenes by enterocin 4 during the manufacture and ripening of Manchego cheese. J. Appl. Microbiol., 83: 671-677.

24. Rossland, E.; Borge, G.I.A.; Langsrud, T.; Sorhaug, T. (2003). Inhibition of Bacillus cereus by strains of Lactobacillus and Lactococcus in milk. Int. J. Food Microbiol., 89:205-212.

25. Sarantinopoulos, P.; Andrighetto, C.; Georgalaki, M.D.; Rea, M.C.; Lombardi, A.; Cogan, T.M.; Kalantzopoulos, G.; Tsakalidou, E. (2001). Biochemical properties of enterococci relevant to their technological performance. Int. Dairy J., 11:621-647.
26. Sarantinopoulos, P.; Leroy, F.; Leontopoulou, E.; Georgalaki, M.D.; Kalantzopoulos, G.; Tsakalidou, E.; De Vuyst, L. (2002). Bacteriocin production by Enterococcus faecium FAIR-E 198 in view of its application as adjunct starter in Greek Feta cheese making. Int. J. Food Microbiol., 72:125-136.

27. Sutra, L.; Mendolia, C.; Rainard, P.; Poutrel, B. (1990). Encapsulation of Staphylococcus aureus isolates from mastitic milk, relationship between capsular polysaccharide type 5 and 8 and colony morphology in serumsoft agar, clumping factor, teichoic acid and protein A. J. Clin. Microbiol., 28:447-451.

28. Vancanney, M.; Kersters, K.; Swings, J. (1999). Catalogue of enterococci of the FAIR-E collection. Published for the EU-project FAIR-CT97-3078 by the BCCM/LMG Bacteria Collection, Gent, Belgium.

29. Wong, H.C.; Chen, C.L.F. (1998). Growth, germination and toxigenic activity of Bacillus cereus in milk products. J. Food Prot., 51:707-710. 